\title{
EFFECT OF TRANSPORTATION DISTANCE ON WEIGHT LOSSES IN PIGS FROM DEHYDRATION
}

Doi:http://dx.doi.org/10.1590/1809-4430-Eng.Agric.v36n6p1229-1238/2016

\section{SIVANILZA T. MACHADO ${ }^{*}$, IRENILZA DE A. NÄ̈̈S², MARIO MOLLO NETO², ODUVALDO VENDRAMETTO ${ }^{2}$, JOÃO G. M. DOS REIS ${ }^{2}$}

${ }^{1 *}$ Corresponding author. Paulista University/ São Paulo - SP, Brazil. E-mail: sivanilzamachado@ifsp.edu.br

\begin{abstract}
The increasing of global demand for food has required more efficiency in the production process. Transportation represents a source of body dehydration for pigs transported from farm to slaughterhouses. This study aimed to evaluate the effects of the distances on the body dehydration of pigs transported to slaughter in tropical conditions. We analyzed 350 pigs shipments with a total of 68,588 heads using statistical software SAS by anova, means and corr procedures. The results showed a liveweight loss estimated at $12 \%$ which was increased gradually as the distance increased as pigs were deprived of water for a long time. The most cost-effective distance for the pigs' transportation under tropical condition is within the range below $100 \mathrm{~km}$, where there were not detected weight losses $(p<0.05)$.
\end{abstract}

KEYWORDS: pre-slaughter logistics, tropical conditions, live weight losses, animal welfare.

\section{INTRODUCTION}

The increasing global demand for food and the food security had required studies about loss reduction (FAO, 2013). Quantifying losses and wastes that happens along productive food chain has been a constant challenge for researchers (RITTER et al., 2009; TEMPLE et al., 2011; DAWKINS, 2012; LEAT \& REVOREDO-GIHA, 2013; REIS et al., 2015). The index for losses in meat production in Latin America is near 22\%, and 1\% refers to the pre-slaughter logistics (FAO, 2011). In Brazil, food losses and waste are estimated in $\$ 12$ billion per year (BCFN, 2012). However, more than financial impacts, it is an important measure the efficiency of the process and reassures an adequate animal treatment and meat quality.

Multifactorial issues related to management, fasting, boarding, drivers' behavior, and transportation, might interfere in pigs' pre-slaughter losses (FITZGERALD et al. 2009; RITTER et al., 2009; BECERRIL-HERRERA et al., 2010; OCHOVE et al., 2010; MARAHRENS et al., 2011). Several variables have been used to assess animal welfare during transportation that has a broad range of effects on pig's physiology. Amongst those, there are heat distress, feed and water deprivation and muscle exertion (SUTHERLAND et al., 2012). Animal distress occurs from loading, journey and unloading activities, and the distress may result in meat loss, named as preslaughter logistic injuries. The percentage of mortality might indicate meat loss, as well as the number of lesions and condemnation rate (KAPELANSKI et al., 2009; MARAHRENS et al., 2011). The transportation also influences meat quality such as the amount of PSE (Pale, Soft, and Exudative), DFD (Dark, Firm, and Dry) meat (OCHOVE et al., 2010; PARANHOS DA COSTA et al., 2012; SANTIAGO et al., 2012), and LwL (Liveweight Losses). The liveweight losses from pig transportation are related to body dehydration that occurs when an animal is under water deprivation for a long time. While waiting to be transported to the slaughterhouse, during the fasting time pigs are not deprived of water. However, during the transportation process water is not given to the pigs that may contribute to distress (LEWIS, 2008), particularly during long distances under heat stress.

Pig production in Brazil is under sub-tropical and tropical climate where a combination of high temperatures and air relative humidity is found. This condition associated with global warming cause heat stress and affects production efficiency and impact in livestock production (SILVA et al.,

\footnotetext{
${ }^{2}$ Paulista University, São Paulo - SP, Brazil.

${ }^{3}$ School of São Paulo State University Julio de Mesquita Filho/Tupã - SP, Brazil.

Received in: 8-17-2015

Accepted in: 7-27-2016
} 
2009; N $\ddot{A} \ddot{A} S$ et al., 2010). Body dehydration is also a usual consequence of long journey under hot weather conditions. Gilts transported after 18 and $30 \mathrm{~h}$, under average ambient temperature 25.8 and $28.6^{\circ} \mathrm{C}$ with a minimum around 17.1 and $17.9^{\circ} \mathrm{C}$ and a maximum of 36.1 and $40.1{ }^{\circ} \mathrm{C}$, presented higher albumin levels, suggesting that dehydration increased with transport duration (SUTHERLAND et al., 2012).

The transportation process is a source of welfare risk, and represent an essential operation for pig production that involves several sectors of the productive chain (BRYER et al., 2011). The effect of distance and transportation conditions in the animal welfare and meat quality have been investigated. Effects of three ranges of transportation distance on pork quality parameters, stress indicators, and mortality rate was assessed by OCHOVE et al. (2010), that found the quality parameters did not affect by distance ranges, but the short distance showed higher number of animals with fatigued signs and long distance showed the higher mortality rate comparing with literature.

Evaluating five effects of transport period on the physiology of breeding age gilts, BRYER et al. (2011), concluded that gilts transported for a period up to $30 \mathrm{~h}$ experience acute stress and change in homeostasis due to dehydration, food deprivation and transport. MARAHRENS et al. (2011), considered animal transport condition to estimate the hazard and risks characterization in qualitatively and quantitatively aspects and the exposure assessment and suggest the guidelines to animal welfare risk assessment on transport need for further investigation and evaluation of multiple scenarios to enable practical relevance, due to general lack of data of transport effect on the animal resulting in a high uncertainty of risk estimates.

However, pig weight or meat losses from transportation under tropical conditions are not assessed yet. Therefore, this study focused on identifying body weight losses from the dehydration of the pigs transported under tropical condition in different ranges of distance extra short, short, medium and long. The appropriate distance for pig transportation to the slaughterhouse was also studied aiming to decrease meat losses and to ensure proper animal welfare in this particular segment of the production chain.

\section{MATERIAL AND METHODS}

Database for this study were provided by a commercial farm located in the State of Mato Grosso do Sul, Brazil $\left(21^{\circ} 15^{\prime} 23^{\prime \prime} \mathrm{S}\right.$ and $\left.52^{\circ} 2^{\prime} 29^{\prime \prime} \mathrm{W}\right)$ and the analysis period was from January to May, 2013. The farm was located in a region with warm weather in summer with air temperature (Ta) range from 21.6 to $32.2{ }^{\circ} \mathrm{C}$ (average $T a=26.3{ }^{\circ} \mathrm{C}, R H=75 \%$, Precipitation $=227.33 \mathrm{~mm}$ ) and cold dry air in winter with air temperature range from 14.8 to $28.4{ }^{\circ} \mathrm{C}$ (average $\mathrm{Ta}=23.3{ }^{\circ} \mathrm{C}$, $R H=52.7 \%$, Precipitation $=25.33 \mathrm{~mm}$ ), the annual precipitation ranges from 19 to $269 \mathrm{~mm}$ (average annual $=1,435 \mathrm{~mm}$ ) (FLUMIGNAN et al., 2015).

\section{Animals, handling, and logistics operations}

Three hundred and fifty shipments of commercial pigs in the finishing stage with 156 days were analyzed. The shipments occurred in 139 double-decker trucks with wooden body type and 211 three-store flatbed trucks with metal body. The double-decker trucks were divided into 12 pens (six on the lower level and six on the top level). For each pen, ten animals were allocated, depending on the weight; meaning up to 120 animals per shipment could be transported. The threestore flatbed trucks had eight pens per store, totaling 24 pens. Up to 10 animals were carried per pen enabling the vehicle to move 240 animals (minimum) and 280 animals (maximum), depending on the weight of the pigs.

For the present study, the shipment was conducted with 110 and 240 pigs per truck respectively, totaling 68,588 heads, with a weight ranging from 90 to $130 \mathrm{~kg}$.

The fasting time applied on the farm was standardized to six hours prior to collection, and animals had access to water until loading. During loading, there was no mixing of batches and ten animals were handled at a time. A sisal bag was used for guiding the animals in the right direction. 
The ramps that gave access to the truck were narrow $(0.80 \mathrm{~m})$ and built with cement, with some parts in bars and metal panels. The fixed part of the loading ramp was made of concrete, and the mobile part was of metal, with slatted floor, to prevent the animal from slipping on smooth surfaces. The loading of animals occurred twice a day, usually in the morning at 7:00h, and in the afternoon at 15:00h.

\section{Treatments}

The classification of the journey period between short and long was based on BENCH et al. (2008), that consider transportation time for journeys between 2 and $9 \mathrm{~h}$ were short, and journeys above $9 \mathrm{~h}$ were found long; and PILCHER et al. (2011), that classified as a long journey period above $3 \mathrm{~h}$. Thus, in the present study we classified as extra short the transportation period for journey up to $2.99 \mathrm{~h}$, short for transportation period between 3 and $3.99 \mathrm{~h}$, medium for transportation period between 4 and $7.99 \mathrm{~h}$ and long for transportation period above $8 \mathrm{~h}$ (Table 1).

TABLE 1. Characteristics of pig's transportation period.

\begin{tabular}{cccccc}
\hline $\begin{array}{c}\text { Transportation } \\
\text { Period }\end{array}$ & $\mathrm{N}$ & $\mathrm{n}^{\prime}$ & Distance $(\mathrm{km})$ & Duration range $(\mathrm{h})$ & Average speed $(\mathrm{km} / \mathrm{h})^{*}$ \\
\hline Extra Short & 29 & 3,360 & Up to 99.99 & Up to 2.99 & 45 \\
Short & 93 & 10,851 & $100-299.99$ & $3-3.99$ & 70 \\
Medium & 115 & 10,200 & $300-499.99$ & $4-7.99$ & 75 \\
Long & 113 & 44,177 & $500-800$ & $8-11$ & 80 \\
\hline
\end{tabular}

The mean values of pigs' weight were estimated before and after transportation period (extra short, short, medium and long period). Thus, the average pig weight on the farm (PWF, kg), average pig weight on arrival at the slaughterhouse (PWAS, $\mathrm{kg}$ ), average weight loss during transportation (WLT, $\mathrm{kg}$ ), and the average weight loss per hour (WLH, $\mathrm{kg}$ ) were determined for four ranges of transportation period. The weight losses that occurred during transportation reflect the difference between the weights of the living animal at loading on the farm and the arrival at the slaughterhouse. The weight loss per hour indicates the relation between the total weight loss and the transportation time from the farm to the slaughterhouse.

\section{Data Analysis}

For the variance analysis, the Duncan test and the Pearson correlation were applied, and significance was set at $p<0.05$. The statistical data processing was conducted using PROC ANOVA, MEANS, GPLOT, and CORR by the computer program SAS, version 9.0 (STATISTICAL ANALYSIS SYSTEM, 2014).

\section{RESULTS AND DISCUSSION}

The distance between the farm and the slaughterhouse ranged from 67 to $716 \mathrm{~km}$. The average weight of the commercialized pig is between 90 and $130 \mathrm{~kg}$, presenting weight losses between 0 and $13.42 \mathrm{~kg}$, which represents weight losses of $12 \%$. The high value of loss liveweight is a response from pigs in stressful environment. The average weight loss per hour was between 0 and $2.99 \mathrm{~kg}$. The body weight loss of pigs increased gradually according to the transportation and ranging from 0 to $13.42 \mathrm{~kg}$ from extra short to long period. The loss occurred in a long transportation period was almost the double compared to the average value in short and medium transportation period (Table 2).

Mortality rate, carcasses showing foot lesions and abrasions, pigs with stress symptoms, and the loss of liveweight usually classify losses by transportation (FITZGERALD et al., 2009). However, these losses are associated with poor animal welfare during pre-slaughter logistics and management. Observing pigs during transportation process is an opportunity to reduce losses, 
because according to TEMPLE et al. (2011), changes in pigs behavioral represent the first level of response of animal to an aversive environment. SUTHERLAND et al. (2012) found the loss of liveweight at extreme temperatures; high density or inadequate practices followed by long duration transport affect pig's physiology. Pigs travelled for 8 and $16 \mathrm{~h}$ presented acidosis, hypocapnia, hypoxemia, hypernatremia, hypercalcemia, higher than normal glucose and increased lactacidemia and hematocrit levels (BECERRIL-HERRERA et al., 2010).

TABLE 2. Descriptive analysis for the weight difference among transportation period extra short, short, medium and long.

\begin{tabular}{ccccccc}
\hline $\begin{array}{c}\text { Transportation } \\
\text { Period }\end{array}$ & $\mathrm{N}$ & $\mathrm{n} \mathrm{n}^{\prime}$ & \multicolumn{4}{c}{ Average weight loss in transportation $(\mathrm{kg})$, per head } \\
\hline & & & Min. & Average & Max. & $\mathrm{SD}$ \\
Extra Short & 29 & 3,360 & 0.00 & 0.00 & 0.00 & 0.00 \\
Short & 93 & 10,851 & 0.22 & 2.24 & 8.97 & 1.18 \\
Medium & 115 & 10,200 & 0.04 & 2.73 & 13.00 & 1.89 \\
Long & 113 & 44,177 & 0.42 & 4.24 & 13.42 & 1.90 \\
Total & 350 & 68,588 & 0.00 & 2.86 & 13.42 & 2.02 \\
\hline $\mathrm{N}=$ number of shipments per transportation period. n’ & $=$ number of pig heads per transportation period. SD = Standard Deviation.
\end{tabular}

In the present study, the total average liveweight loss during transportation was 196.16 tons for the analyzed periods, which represents about 39.23 tons per month or even an estimated 470.78 tons per year. REIS et al. (2015) studying occurrence of losses in pork supply chain in tropical conditions estimated a total of US\$159,990.00 per year.

Animal welfare is a usual concept applied by the farmers during the production stages in Brazil. Farmers understand animal welfare as a practice to reach more productivity due to produce a competitive animal (SANTIAGO et al., 2012). However, animal welfare involved in the transportation processes is under different perception by pig farmers. Transportation guidelines are used in developed countries (United States, Canada, and European Union) different from the scenario in undeveloped countries (BENCH et al., 2008; BRYER et al., 2011; EUROPEAN COMMISSION, 2011). In Brazil, a lack of good management in some links of the meat chain leads to economic losses (REIS et al., 2015). Guidelines are developed by organizations like the Brazilian Agricultural Research Corporation Pork \& Poultry (EMBRAPA), National Program on Humane Slaughter (STEPS program) and Ethology and Animal Ecology Research Group (ETCO). For example, from 2009 up to 2010, EMBRAPA Suínos \& Aves and STEPS program provided a personnel training initiatives to improve livestock welfare in Brazil and this reached more than 250 drivers and 1,500 professionals in 217 slaughter plants, respectively (PARANHOS DA COSTA et al., 2012). However, the booklets for best practices in livestock management are solely recommendation for helping farmers on production and animal welfare issues.

The body weight of the pigs on the farm differed for all transportation period $(p<0.05)$, with averages between 102 and $115 \mathrm{~kg}$. Already the pig body weight on the arrival at the slaughterhouse were similar to extra short, short and long, these differed statistically from medium $(p<0.05)$. However, the biggest difference comparing the body weight averages at the slaughterhouse and on the farm occurred between long, medium and short transportation period respectively, representing a loss of body weight during the transportation of pigs. These results disagree with PILCHER et al. (2011) that did not find effects of short and long time on total losses $(0.24 \%)$. Short and medium transportation period showed similar results, and there were no differences among them, but they differed by the Duncan test in relation to the extra short and long transportation period $(p<0.05)$. The loss of body weight per hour followed a similar pattern, and short and medium transportation period did not differ $(p>0.05)$. However, both differed from extra short and long period $(p<0.05)$ (Table 3). Similar result was obtained by GOSÁLVEZ et al. (2006) who found that the transportation distance affects the mortality rate, the loss of liveweight and yield $(p<0.001)$. 
TABLE 3. Average values for the variables PWF, PWAS, WLT, and WLH, transportation period.

\begin{tabular}{ccccc}
\hline $\begin{array}{c}\text { Transportation } \\
\text { Period }\end{array}$ & PWF $^{*}$ & PWAS & WLT* & WLH \\
\hline Extra Short & $102.38^{\mathrm{d}}$ & $102.38^{\mathrm{b}}$ & $0.0^{\mathrm{c}}$ & $0.0^{\mathrm{c}}$ \\
Short & $105.54^{\mathrm{c}}$ & $103.30^{\mathrm{b}}$ & $2.24^{\mathrm{b}}$ & $0.74^{\mathrm{a}}$ \\
Medium & $114.97^{\mathrm{a}}$ & $112.24^{\mathrm{a}}$ & $2.73^{\mathrm{b}}$ & $0.41^{\mathrm{b}}$ \\
Long & $107.88^{\mathrm{b}}$ & $103.64^{\mathrm{b}}$ & $4.24^{\mathrm{a}}$ & $0.47^{\mathrm{b}}$
\end{tabular}

*Values $(\mathrm{kg})$ followed by the same letter in column do not differ statistically from $p<0.05$, according to the Duncan test.

The highest concentration of body weight losses occurred to pigs transported over $300 \mathrm{~km}$, in medium and long transportation period, which showed cumulative losses of 32 and $48 \%$ respectively. Weight loss also occurred in short transportation period, at a lesser proportion (20\%) (Figure 1).

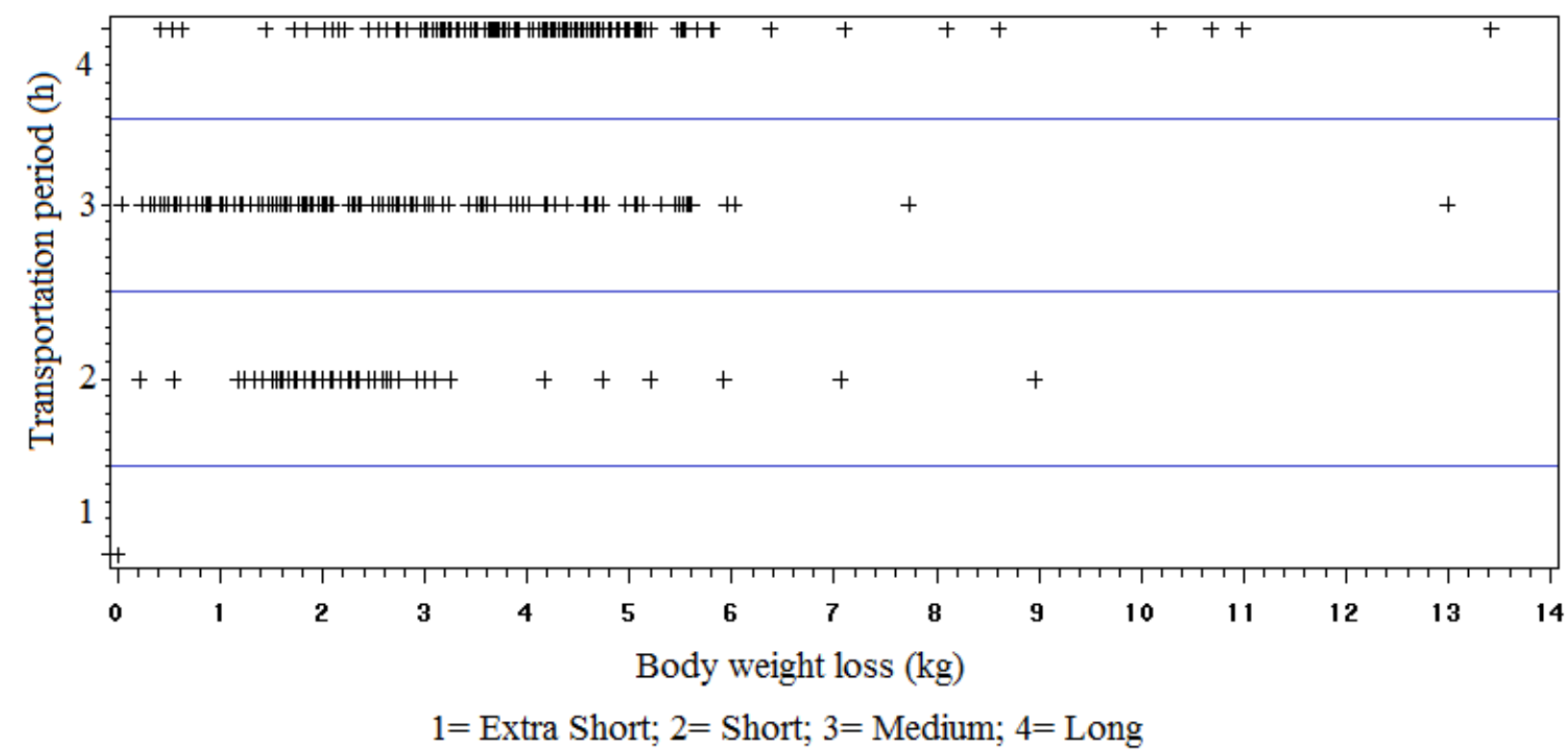

FIGURE 1. Loss of body weight in pigs transported from the farm to the slaughterhouse, per transportation period.

Animals transported to long distance are exposed to variation in temperatures and air humidity, wind, long food and water deprivation. In the present study, the pigs transported during summer were under average air temperature $25.6 \pm 1.52\left(16.9\right.$ to $\left.36.8{ }^{\circ} \mathrm{C}\right)$ and average relative humidity $71.4 \pm 12.3 \%$ (16 to $100 \%)$ and in autumn under average air temperature $21.3 \pm 2.84^{\circ} \mathrm{C}(5.1$ to $33.7^{\circ} \mathrm{C}$ ) and average relative humidity $78.0 \pm 10.1 \%$ (16 to $\left.100 \%\right)$. Under tropical conditions, pigs presented a high respiration rate in the afternoon and moderate in the morning (HUYNH et al., 2006). In addition, the authors reported that the group of pigs in control treatment showed skin temperature higher than pigs under other treatments with cooling facilities. Thus, pigs under hot weather conditions react by maintaining high respiration rate and skin temperature, and it is critical to the production to use cooling systems in order to reduce animal heat stress in warm climates.

Assessing PSE pork GAJANA et al. (2013), found higher incidences of PSE in animals travelled during summer and autumn season associated as to effects of temperatures in South Africa. Similar results were found by SANTIAGO et al. (2012), that shows $10 \%$ of the PSE pork from 2,128 carcasses evaluated. Despite the high value of PSE pork, SANTIAGO et al. (2012) suggest that PSE could be higher due to transportation process under tropical conditions. Authors indicated that fasting time for 6 and $8 \mathrm{~h}$ applied in animals after transportation in hot weather was a contribution to results. 
Management decision and climate information needs to incorporated into management tools that involved livestock production, in order to reduce impact of global warming in production and its influence the future increase on Brazilian production (NÄ̈̈S et al., 2010). In addition, package of information about real conditions from producers and consumers, provide base to decisions concerning actually welfare, safety, environment and the cost of production (DAWKINS et al., 2012). On the other hands, with the growing concern about food systems, the food supply chain has a challenge to management the food safety, sustainable, and meet consumers' expectations (LEAT \& REVOREDO-GIHA, 2013).

In the current study, pigs transported a distance smaller than $100 \mathrm{~km}$ under summer and autumn condition of the state of Mato Grosso do Sul did not present loss of body weight. FITZGERALD et al. (2009) assessed three different distances from the farm to the slaughterhouse, under humid continental climate, with average annual temperature of $12.69^{\circ} \mathrm{C}$, with extreme hot and cold season (variation $=-21.78$ to $36.13^{\circ} \mathrm{C}$ ), the weight losses were above $1.0 \%$ for the transportation of animals over distances beyond $80 \mathrm{~km}$; below $0.5 \%$ for distances of 40 and $80 \mathrm{~km}$. Distances smaller than $40 \mathrm{~km}$ have not had losses $(p=0.14)$ because the average values were smaller than the total losses of animals transported in a distance higher than $80 \mathrm{~km}$. GAJANA et al. (2013) reported that transportation time and stocking density more than $0.4 \mathrm{~m}^{2} / 100 \mathrm{~kg}$ pig influence in PSE pork.

The results of the present study suggest that the most cost-effective distance for pigs' transportation to slaughter is below $100 \mathrm{~km}$. According to KAPELANSKI et al. (2009), pigs transported distances higher than $100 \mathrm{~km}$ showed higher body weight losses than pigs transported over $30 \mathrm{~km}$, with $2.09 \%$ and $1.16 \%$ ( $p<0.01)$ respectively. SILVA \& KALUBOWILA (2012) suggest that the transportation of pigs from the farm to the slaughterhouse should not exceed $55 \mathrm{~km}$.

Besides the long distance travelled, pigs suffer from other sources of distress such as the mixing of batches, human-animal interaction, physical changes like the ramp, floor and vehicle movement, exposure to the environment (temperature, humidity and radiation), and fasting (FITZGERALD et al., 2009). Inside the truck, environmental condition is a crucial factor to reduce body weight loss during animal transportation, as large amount of fluids due to panting and sweating are lost (MIRANDA-DE LA LAMA et al., 2014).

The distress induced by the management of truck loading, allied to the novelty of the transport associated with the length of the journey, increases the risk of dehydration, metabolic and physical fatigue (OCHOVE et al., 2010; SUTHERLAND et al., 2012). EDWARDS et al. (2010) found higher and greater change on blood lactate concentration occurred in pigs post-loading on truck $(p=$ $0.002)$ and during loading $(p=0.0006)$ increased $\mathrm{pH}_{\mathrm{u}}$. BRYER et al. (2011) reported that gilts transported to a period of the $30 \mathrm{~h}$ showed an increase in physiological acute stress, dehydration, and muscle breakdown. LEWIS (2008), reported that animals increased drinking post-transport to replace water losses that occurred during the transportation process. The higher the body weight of the pig on the farm, the greater the loss of the pig body weight upon arrival at the slaughterhouse (Table 4). 
TABLE 4. Average weight loss during pig transportation by body weight range on the farm.

\begin{tabular}{ccccccc}
\hline Weight Range $(\mathrm{kg})^{*}$ & $\mathrm{~N}$ & $\mathrm{n}^{\prime}$ & Extra Short $^{+}$ & Short $^{+}$ & Medium $^{+}$ & Long $^{+}$ \\
\hline Up to 100 & 32 & 4,110 & 0.00 & $2.12^{\mathrm{b}}$ & $2.44^{\mathrm{ab}}$ & $1.85^{\mathrm{b}}$ \\
$101-110$ & 169 & 31,982 & 0.00 & $2.08^{\mathrm{b}}$ & $3.18^{\mathrm{a}}$ & $3.49^{\mathrm{ab}}$ \\
$111-120$ & 126 & 27,755 & 0.00 & $3.00^{\mathrm{a}}$ & $2.17^{\mathrm{ab}}$ & $3.67^{\mathrm{ab}}$ \\
$>121$ & 23 & 4,741 & 0.00 & $3.12^{\mathrm{a}}$ & $1.19^{\mathrm{b}}$ & $4.17^{\mathrm{a}}$ \\
Total & 350 & 68,588 & 0.00 & 10.63 & 8.98 & 13.18 \\
\hline
\end{tabular}

*average body weight of pigs before transportation $(\mathrm{kg}) . \mathrm{N}=$ number of shipments. $\mathrm{n}$ ' = number of pig heads per weight range. +Values (kg) followed by the same letter in column do not differ statistically from $p<0.05$, according to the Duncan test.

Pigs with the weight ranging between 110 and $120 \mathrm{~kg}$ as well as above $120 \mathrm{~kg}$ showed greater weight loss during transport. Positive correlations $(p<0.001)$ between the pigs' weight on the farm, pigs' weight on arrival and the liveweight loss during transportation is found in relation to the transportation period $(0.305,0.169$ and 0.328 , respectively). The larger the offset distance, the greater the animals' weight loss. PWAS $(0.951, p<0.0001)$ and WLT $(0.127, p<0.05)$ showed positive correlation with PWF, just as expected. This result agrees with the studies of SILVA \& KALUBOWILA (2012) who found a high correlation between carcass weight and liveweight. A linear increase was found related to carcass weight, and with the liveweight for slaughter. EDWARDS et al. (2010) reported consistent relationships between the phase of animal lodging on the farm and meat quality parameters. Positive correlation $(p<0.01)$ was found between WLT and WLH $(0.722, p<0.001)$. The variable WLH is the relationship between the liveweight losses during transportation and the transport time between the farm and the slaughterhouse.

The appropriate time of fasting contributes to the reduction of the mortality rate in transportation. In this study, the applied a total fasting time (resting time before transport and journey duration) for the animals ranged from 8 to 17 hours. The eight hours fasting time did not lead to body weight loss in pigs. However, losses increased with the increased fasting time, estimated at an average of $2.24 \mathrm{~kg}$ for nine hours, $2.68 \mathrm{~kg}$ for 12 hours and $4.24 \mathrm{~kg}$ for 15 hours. The fasting time added to the time on transportation (distance and journey time) had adverse effects on body weight loss through dehydration and animal stress, and consequently decrease carcass yield. However, BENCH et al. (2008) found that losses in the carcass yield appeared to a fasting time above 18 hours.

In the present study, the losses for pigs' body dehydration in the productive chain represent $12 \%$ assessed only liveweight of pigs.

\section{CONCLUSIONS}

Distances higher than $300 \mathrm{~km}$ between the farm and the slaughterhouse showed large pig' body weight losses under summer and autumn condition of the state of Mato Grosso do Sul. This loss represents great economic impact for pig farmers, and less carcass yield. The ideal distance for transporting pigs is smaller than $100 \mathrm{~km}$ when considering no loss in liveweight loss.

\section{ACKNOWLEDGEMENTS}

To Coordenação de Aperfeiçoamento de Pessoal de Nível Superior (CAPES) and Conselho Nacional de Desenvolvimento Científico e Tecnológico (CNPq) for the research grant.

\section{REFERENCES}

BCFN, BARILLA CENTER FOR FOOD AND NUTRITION. Food waste: causes, impacts and proposals. Parma: Barrila, 2012. Disponível em: <http://www.barillacfn.com/wpcontent/uploads/2012/11/WEB_ENG.pdf>. Acesso em: 5 mar. 2015. 
BECERRIL-HERRERA, M.; ALONSO-SPILSBURY, M.; ORTEGA, M.E.T.; GUERREROLEGARRETA, I.; RAMÍREZ-NECOECHEA, R.; ROLDAN-SANTIAGO, P.; PÉREZ-SATO, M.; SONÍ-GUILLERMO, E.; MOTA-ROJAS, D. Changes in blood constituents of swine transported for 8 or 16 h to an Abattoir. Meat Science, Amsterdam, v.86, n.4, p.945-948, dez. 2010.

BENCH, C.; SCHAEFER, A.L; RUSHEN, J.P.; PASSILLÉ, A.M.; FAUCITANO, L.; LEWIS, N.; GONYOU, H.; BERGERON, R.; WIDOWSKI, T. Welfare implication of pig transport journey duration: scientific background of current international standards. Ottawa: Agriculture and AgriFood Canada, 2008. Disponível em: 〈http://www.pigsatrisk.com/documents/journey_duration.pdf >. Acesso em: 20 fev. 2015.

BRYER, P.J.; SUTHERLAND, M.A.; DAVIS, B.L.; SMITH, J.F.; MCGLONE, J.J. The effect transport and space allowance on the physiology of breeding age gilts. Livestock Science, Amsterdam, v.137, n.1-3, p. 58-65, maio 2011.

DAWKINS, M.S. Commercial scale research and assessment of poultry welfare. British Poultry Science, Edinburg, v. 53, n.1, p. 1-6, fev. 2012.

EDWARDS, L.N.; GRANDIN, T.; ENGLE, T.E.; RITTER, M.J.; SOSNICKI, A.A.; CARLSON, B.A.; ANDERSON, D.B. The effects of pre-slaughter pig management from the farm to the processing plant on pork quality. Meat Science, Amsterdam, v.86, p. 938-944, dez. 2010.

EUROPEAN COMMISSION. Report: on the impact of Council Regulation (EU) No 1/2005 on the protection of animal during transport. Brussels: European Comission, 2011. Disponível em: <http://ec.europa.eu/food/animal/welfare/transport/docs/10112011_report_en.pdf >. Acesso em: 10 jan. 2015.

FAO - FOOD AND AGRICULTURE ORGANIZATION OF THE UNITED NATIONS. Global food losses and food waste. Düsseldorf: FAO, 2011. Disponível em:

<http://fvm.dk/fileadmin/user_upload/FVM.dk/Dokumenter/Landbrug/Indsatser/Madspild/FAO_ra pport_madspild.pdf>. Acesso em: 5 mar. 2015.

FAO - FOOD AND AGRICULTURE ORGANIZATION OF THE UNITED NATIONS. FAO statistical yearbook 2013: world food and agriculture. Rome: FAO, 2013. Disponível em: <http://www.fao.org/docrep/018/i3107e/i3107e00.htm>. Acesso em: 14 fev. 2015.

FITZGERALD, R.F.; STALDER, K.J.; MATTHEWS, J.O.; SCHULTZ KASTER, C.M.; JOHNSON, A.K. Factors associated with fatigued, injured, and dead pig frequency during transport and lairage at a commercial abattoir. Journal Animal Science, Champaign, v.87, n.3, p.1156-1166, 2009.

FLUMIGNAN, D.L.; FIETZ, C.R.; COMUNELLO, E. O clima na região do Bolsão de Mato Grosso do Sul. Dourados: Embrapa Agropecuária Oeste, 2015. p. 42, 2015.

GAJANA, C.S.; NKUKWANA, T.T.; MARUME, U.; MUCHENJE, V. Effects of transportation time, distance, stocking density, temperature and lairage time on incidences of pale soft exudative (PSE) and the physic-chemical characteristics of pork. Meat Science, Amsterdam, v.95, n.3, p. 520525, nov. 2013.

GOSÁLVEZ, L.F.; AVERÓS, X.; VALDELVIRA, J.J.; HERRANZ, A. Influence of season, distance and mixed loads on the physical and carcass integrity of pigs transported to slaughter. Meat Science, Amsterdam, v.73, n.4, p.553-558, ago. 2006.

HUYNH, T.T.T., AARNINK, A.J.A.; TRUONG, C.T.; KEMP, B.; VERSTEGEN, M.W.A. Effects of tropical climate and water cooling methods on growing pigs' responses. Livestock Science, Amsterdam, v.104, n.3, p.278-291, nov. 2006.

KAPELANSKI, W.; HAMMERMEISTER, A.; GRAJEWSKA, S.; BOCIAN, M., WISNIEWSKA, J. Effect of pre-slaughter handling on body weight loss and carcass and meat quality in crossbred fatteners. Animal Science Papers and Reports, Warszawa, v.27, n.4, p.343-351, 2009. 
LEAT, P.; REVOREDO-GIHA, C. Risk and resilience in agri-food supply chains: the case of the ASDA PorkLink supply chain in Scotland. Supply Chain Management an International Journal, Bradford, v.18, n.2, p. 219-231, 2013.

LEWIS, N.J. Transport of early weaned piglets. Applied Animal Behavior Science, New York, v.110, n.1-2, p.128-135, mar. 2008.

MARAHRENS, M.; KLEINSCHMIDT, N.; DI NARDO, A.; VELARDE, A.; FUENTES, C.; TRUAR, A.; OTERO, J.L.; DI FEDE, E.; DALLA VILLA, P. Risk assessment in animal welfare especially referring to animal transport. Preventive Veterinary Medicine, Amsterdam, v.102, n.1, p.157-163, nov. 2011.

MIRANDA-DE LA LAMA, G.C.; VILLARROED, M.; MARÍA, G.A. Livestock transport from the perspective of the pre-slaughter logistic chain: a review. Meat Science, Amsterdam, v.98, n.1, p.920, set. 2014.

NÄÄS, I.A.; ROMANINI, C.E.B.; SALGADO, D.D’A.; LIMA, K.A.O.; VALE, M.M.; LABIGALINI, M.R.; SOUZA, S.R.L.; MENEZES, A.G.; MOURA, D.J. Impact of global warming on beef cattle production cost in Brazil. Scientia Agricola, Piracicaba, v.67, n.1, p. 1-8, jan./fev. 2010.

OCHOVE, V.C.C.; CARAMORI JÚNIOR, J.G.; CORRÊA, G.S.S.; BERTOLONI, W.; ROÇA, R. O.; SILVA, G.S.; CRUZ, R.A.S. Influência da distância no bem-estar e qualidade de carne de suínos transportados em Mato Grosso. Revista Brasileira de Saúde e Produção Animal, Salvador, v. 11, n.4, p. 1117-1126, out./dez. 2010.

PARANHOS DA COSTA, M.J.R.; HUERTAS, S.M.; GALLO, C.; DALLA COSTA, O.A. Strategies to promote farm animal welfare in Latin America and their effects on carcass and meat quality traits. Meat Science, Amsterdam, v. 92, n.3, p. 221-226, nov. 2012.

PILCHER, C.M.; ELLIS, M.; ROJO-GÓMEZ, A.; CURTIS, S.E.; WOLTER, B.F.; PETERSON, C.M.; PETERSON, B.A.; RITTER, M.J.; BRINKMANN, J. Effects of floor space during transport and journey time on indicators of stress and transport losses of market-weight pigs. Journal Animal Science, Champaign, v. 89, p. 3809-3818, maio 2011.

REIS, J.G.M.; MACHADO, S.T.; SANTOS, R.C.; NÄÄS, I.A.; OLIVEIRA, R.V. Financial losses in pork supply chain: a study of the pre-slaughter handling impacts. Engenharia Agrícola, Jaboticabal, v.35, n.1, p.163-170, 2015.

RITTER, M.J.; ELLIS, M.; BERRY, N.L.; CURTIS, S.E.; ANIL, L.; BERG, E.; BENJAMIN, M.; BUTLER, D.; DEWEY, C.; DRIESSEN, B.; DUBOIS, P.; HILL, J.D.; MARCHANT-FORDE, J.N.; MATZAT, P.; MCGLONE, J.; MORMEDE, P.; MOYER, T.; PFALZGRAF, K.; SALAKJOHNSON, J.; SIEMENS, M.; STERLE, J.; STULL, C.; WHITING, T.; WOLTER, B.; NIEKAMP, S. R.; JOHNSON, A.K. Transport losses in market weight pigs: I. A review of definitions, incidence, and economic impact. The Professional Animal Scientist, Savoy, v.25, n.4, p.404-414, ago. 2009.

SANTIAGO, J.C.; CALDARA, F.R.; SANTOS, V.M.O.; SENO, L.O.; GARCIA, R.G.; ALMEIDA PAZ, I.C.L. Incidência da carne PSE (pale, soft, exsudative) em suínos em razão do tempo de descanso pré-abate e sexo. Arquivo Brasileiro de Medicina Veterinária e Zootecnia, Belo Horizonte, v. 64, n.6, p. 1739-1746, dez. 2012.

SILVA, B.N.; NOBLET, J.; DONZELE, J.L.; OLIVEIRA, R.F.M.; PRIMOT, Y.; GOURDINE, J.L.; RENAUDEAU, D. Effects of dietary protein level and amino acid supplementation on performance of mixed-parity lactating sows in a tropical humid climate. Journal of Animal Science, Champaign, v.87, n.12, p.4003-4012, dez. 2009.

SILVA, P.; KALUBOWILA, A. Relationship of transport distance, sex on live weight loss of pigs during transit to slaughter house. Veterinary World, Raykot, v.5, n.3, p.150-154, mar. 2012.

STATISTICAL ANALYSIS SYSTEM. SAS/STAT 13.2 user's guide. North Carolina, 2014. 9284 p. 
SUTHERLAND, M.A.; BRYER, P.J.; DAVIS, B.L.; SMITH, J.F.; MCGLONE, J.J. The combined effects of transport and food and water deprivation on the physiology of breeding age gilts.

Livestock Science, Amsterdam, v.144, n.1-2, p.124-131, mar. 2012.

TEMPLE, D.; MANTECA, X.; VELARDE, A.; DALMAU, A. Assessment of animal welfare through behavioural parameters in Iberian pigs in intensive and extensive conditions. Applied Animal Behaviour Science, New York, v. 131, n.1-2, p. 29-39, abr. 2011. 